\title{
Corrigendum: Integration and regulation of glomerular inhibition in the cerebellar granular layer circuit
}

\author{
Lisa Mapelli ${ }^{1,2}$, Sergio Solinas ${ }^{1 *}$ and Egidio D'Angelo ${ }^{1,2}$ \\ ${ }^{\prime}$ Brain Connectivity Center, C. Mondino National Neurological Institute, Pavia, Italy \\ ${ }^{2}$ Department of Brain and Behavioral Sciences, University of Pavia, Pavia, Italy \\ *Correspondence: solinas@unipv.it
}

Edited and reviewed by:

Tycho M. Hoogland, Netherlands Institute for Neuroscience, Netherlands

Keywords: synaptic inhibition, gaba receptors, granule cells, golgi cells, cerebellum

\section{A Corrigendum on}

Integration and regulation of glomerular inhibition in the cerebellar granular layer circuit

by Mapelli, L., Solinas, S., and D'Angelo, E. (2014). Front. Cell Neurosci. 8:55. doi: 10.3389/fncel.2014.00055

Sergio Solinas is affiliated exclusively with the Brain Connectivity Center, C.
Mondino National Neurological Institute, Pavia, Italy.

Conflict of Interest Statement: The authors declare that the research was conducted in the absence of any commercial or financial relationships that could be construed as a potential conflict of interest.

Received: 03 October 2014; accepted: 04 October 2014; published online: 20 October 2014.

Citation: Mapelli L, Solinas S and D'Angelo E (2014)

Corrigendum: Integration and regulation of glomerular inhibition in the cerebellar granular layer circuit. Front. Cell. Neurosci. 8:342. doi: 10.3389/fncel.2014.00342 This article was submitted to the journal Frontiers in Cellular Neuroscience.

Copyright () 2014 Mapelli, Solinas and D’Angelo. This is an open-access article distributed under the terms of the Creative Commons Attribution License (CC BY). The use, distribution or reproduction in other forums is permitted, provided the original author(s) or licensor are credited and that the original publication in this journal is cited, in accordance with accepted academic practice. No use, distribution or reproduction is permitted which does not comply with these terms. 